\title{
PENGARUH METODE PEMBELAJARAN PAKTIKUM PEER TEACHING TERHADAP PRAKTIK VULVA HYGIENE PADA MAHASISWA DIII KEBIDANAN FAKULTAS KEDOKTERAN UNS
}

\author{
The Influence Of Peer Teaching Pakticum Learning Method On Vulva Hygiene \\ Practices In Students DIII Midwifery \\ Faculty Of Medicine UNS
}

\author{
Sri Anggarini Parwatiningsih ${ }^{1}$, Ropitasari ${ }^{2}$, M.Nur Dewi Kartikasari ${ }^{3}$ \\ Program Studi D III Kebidanan Fakultas Kedokteran UNS \\ (ropita.uns@gmail.com)
}

\begin{abstract}
ABSTRAK
Latar Belakang: Pelayanan bidan yang profesional harus dipersiapkan sejak perkuliahan. agar menjadi bidan professional, maka mahasiswa kebidanan harus belajar dengan tekun, baik secara mandiri maupun dengan teman sebaya. Salah satu metode belajar yang dapat diterapkan adalah metode peer teaching (tutor sebaya), merupakan latihan mengajar yang dilakukan oleh siswa kepada kepada siswa lainnya dan mendorong siswa tersebut lebih memahami materi yang akan diajarkan. Metode pembelajaran praktikum secara peer teaching efektif diterapkan pada kegiatan praktikum khususnya pada praktik vulva hygiene sebagai salah satu kompetensi dasar bidan.

Tujuan penelitian adalah untuk mengetahui pengaruh metode pembelajaran praktikum peer teaching terhadap praktik vulva hygiene pada mahasiswa DIII kebidanan FK UNS.

Metode Penelitian: Pre-experimental dengan rancangan pretest-posttest one group design. Teknik sampling menggunakan purposive sampling yaitu 36 mahasiswa. Instrumen penelitian menggunakan checklist penilaian praktik vulva hygiene. Penelitian ini menggunakan uji statistik paired t-test.

Hasil Penelitian: Hasil praktik vulva hygiene sebelum diberikan metode pembelajaran praktikum peer teaching didapatkan rerata 66,36 dan setelah diberikan metode pembelajaran praktikum peer teaching didapatkan rerata 82,39. Dari hasil penelitian didapatkan nilai t sebesar 31.909 dan p sebesar 0.000 .

Simpulan: Ada pengaruh metode pembelajaran praktikum peer teaching terhadap praktik vulva hygiene pada mahasiswa DIII Kebidanan Fakultas Kedokteran UNS.
\end{abstract}

Kata kunci : Metode pembelajaran, peer teaching, vulva hygiene 


\begin{abstract}
Background: Professional midwife services must be prepared since lectures to become a professional midwife, midwifery students must study diligently, both independently and with peers. One learning method that can be applied is the method of peer teaching (peer tutors), a teaching exercise conducted by students to other students and encourages students to better understand the material to be taught. Peer teaching methods of practical learning are effectively applied to practicum activities especially in the practice of vulva hygiene as one of the basic competencies of midwives.

The purpose of this study was to determine the effect of peer teaching practicum learning methods on the practice of vulva hygiene in DIII students midwifery of FK UNS.

Methods: Pre-experimental with pretest-posttest one group design. The sampling technique used purposive sampling, namely 36 students. The research instrument used the vulva hygiene practice assessment checklist. This study uses a paired $t$ test statistical test.

Results: The results of the practice of vulva hygiene before being given a peer teaching practicum learning method obtained an average of 66.36 and after being given a peer teaching practicum learning method obtained an average of 82.39. From the research results obtained $t$ value of 31.909 and $p$ of 0.000 .

Conclusion: There is an effect of peer teaching practicum learning methods on the practice of vulva hygiene in the DIII of students Midwifery Medical Faculty UNS.
\end{abstract}

Keywords: Learning methods, peer teaching, vulva hygiene

\title{
PENDAHULUAN
}

Tuntutan masyarakat terhadap profesi bidan adalah memberikan pelayanan secara profesional, oleh karena itu bidan harus menguasai sembilan standar kompetensi yang terdapat dalam Keputusan Menteri Kesehatan RI Nomor: 369/Menkes/SK/III/2007. Salah satunya adalah melakukan pertolongan persalinan abnormal letak sungsang (IBI, 2013).

Pelayanan bidan yang profesional harus dipersiapkan sejak di bangku kuliah. Salah satu metode belajar yang efektif dalam belajar adalah metode peer teaching (tutor sebaya) yang merupakan latihan mengajar yang dilakukan oleh siswa kepada teman-teman. (Majid, 2014).

Pembelajaran praktik vulva hygiene yang biasanya dilaksanakan di kelas dan laboratorium dengan metode demonstrasi, role play, dan bedside teaching. Kegiatan pembelajaran di laboratorium yang berpusat pada pendidik mengakibatkan peserta didik hanya memperhatikan dan mencatat informasi yang disampaikan oleh pendidik dan tidak memberikan kesempatan kepada peserta didik untuk berperan aktif dalam pembelajaran, sehingga menyebabkan aktivitas belajar peserta didik tidak optimal (Jufna, 2012). 


\section{METODE PENELITIAN}

Jenis penelitian ini menggunakan metode kuantitatif dengan desain penelitian pre-experimental pretest-posttest one group design. Teknik pengambilan sampel menggunakan purposive sampling. Sampel dalam penelitian ini adalah seluruh mahasiswa semester III Prodi DIII Kebidanan FK UNS sebanyak 36 orang. Mahasiswa yang menjadi tutor dipilih dari yang terbaik berdasarkan hasil pretest dan memenuhi kriteria tertentu yang telah ditetapkan. Mahasiswa yang menjadi tutor dipilih dari yang terbaik berdasarkan hasil pretest dan memenuhi kriteria tertentu yang telah ditetapkan oleh peneliti. Mahasiswa yang menjadi tutee adalah semua mahasiswa yang bukan terpilih menjadi tutor dan masuk kriteria inklusi yaitu berjumlah 36 mahasiswa yang kemudian dibagi menjadi 4 kelompok tutee, dimana masing-masing kelompok tutee beranggotakan 14-15 orang.

Intervensi yang telah dilakukan dalam penelitian ini adalah dengan memberikan pretest pada mahasiswa sebelum dilaksanakan metode pembelajaran peer teaching, setelah itu memberikan perlakuan berupa pembelajaran dengan metode peer teaching dan yang terakhir dengan melakukan posttest

Instrumen atau alat yang digunakan dalam penelitian ini menggunakan alat pengumpulan data berupa checklist atau daftar tilik. Menilai sesuai daftar tilik dengan rating scale $0-1$, dimana penilaian $0=$ jika tindakan tidak dilakukan dan atau dilakukan tapi belum benar, 1=jika tindakan dilakukan dengan benar. Alat yang diperlukan selanjutnya seperti media phantom perempuan dewasa dengan vulva, peralatan ketrampilan vulva hygiene dan tempat yang digunakan yaitu laboratorium. Hasil penilaian ketrampilan kemudian dilakukan analisis data dengan menggunakan Uji t berpasangan (paired $t$ - test)

\section{HASIL DAN PEMBAHASAN}

\section{Hasil}

1. Perolehan nilai pretest pada praktik vulva hygiene dapat dilihat di tabel ini :

Tabel 1. Analisis Hasil Pretest Praktik Vulva Hygiene Mahasiswa DIII Kebidanan FK UNS

\begin{tabular}{clc}
\hline No & \multicolumn{1}{c}{ Analisis } & Hasil \\
\hline 1. & Mean (rerata) & 66,36 \\
2. & Median & 67,23 \\
3. & Modus & 58,10 \\
4. & Standar Deviasi & 4,62 \\
5. & Nilai tertinggi & 79,73 \\
6. & Nilai terendah & 58,10 \\
\hline
\end{tabular}


Berdasarkan tabel 1 didapatkan hasil nilai pretest praktik vulva hygiene sebelum diberikan metode pembelajaran peer teaching pada 36 responden dapat disimpulkan bahwa mahasiswa yang nilai pretest berada di bawah KKM ada 28 orang $(77,8 \%)$ dan yang di atas KKM ada 8 orang $(22,2 \%)$.

2. Perolehan nilai posttest pada praktik vulva hygiene dapat dilihat pada tabel di bawah ini :

Tabel 2. Analisis Hasil Posttest Praktik vulva hygiene Mahasiswa DIII Kebidanan FK UNS

\begin{tabular}{cll}
\hline No & \multicolumn{1}{c}{ Analisis } & Hasil \\
\hline 1. & Mean (rerata) & 82,39 \\
2. & Median & 81,70 \\
3. & Modus & 73,83 \\
4. & Standar Deviasi & 6,43 \\
5. & Nilai tertinggi & 98,33 \\
6. & Nilai terendah & 73,83
\end{tabular}

Berdasarkan tabel 2 didapatkan hasil nilai pretest praktik vulva hygiene sebelum diberikan metode pembelajaran peer teaching pada 36 responden dapat disimpulkan bahwa semua mahasiswa (100\%) mendapatkan nilai posttest di atas KKM.

3. Analisis bivariat dilakukan untuk mengetahui pengaruh metode pembelajaran praktikum peer teaching terhadap praktik vulva hygiene Analisis yang digunakan adalah dengan menggunakan uji normalitas Saphiro-wilk terlebih dahulu, didapatkan hasil sebagai berikut:

Tabel 3. Hasil uji normalitas nilai sebelum dan sesudah dilakukan metode peer teaching pada praktik pertolongan letak sungsang dengan Saphirowilk

\begin{tabular}{lcc}
\hline Pencapaian & $\mathrm{p}$ (Sig.) \\
\hline Nilai & $\begin{array}{r}\text { sebelum } \\
\text { (pretest) }\end{array}$ & 0,200 \\
Nilai & $\begin{array}{r}\text { sesudah } \\
\text { (posttest) }\end{array}$ & 0,100 \\
\hline
\end{tabular}

4. Analisis lanjutan yang digunakan adalah uji $\mathrm{T}$ berpasangan (paired $t$-test), dan didapatkan hasil sebagai berikut :

Tabel 4. Perbedaan pencapaian nilai praktik vulva hygiene pada mahasiswa sebelum dan sesudah dilakukan metode pembelajaran praktikum peer teaching 
Jurnal Kebidanan Indonesia. Vol 11 No 1. Januari 2020 (90 - 97)

\begin{tabular}{lllll}
\hline & Rerata & $\begin{array}{l}\text { Standar } \\
\text { Deviasi }\end{array}$ & t & P (Sig. 2-tailed) \\
\hline $\begin{array}{l}\text { Nilai } \\
\text { sebelum } \\
\text {-nilai } \\
\text { sesudah }\end{array}$ & -16.029 & 3.014 & -31.909 & 0.000 \\
\hline
\end{tabular}

Berdasarkan hasil analisis didapatkan hasil dari 36 responden terjadi peningkatan rerata sebesar 16.029, kemudian didapatkan nilai signifikan $\mathrm{p}$ sebesar 0.000 dan $t_{\text {hitung }}$ sebesar 31.909. Jadi dapat disimpulkan ada pengaruh metode pembelajaran praktikum peer teaching terhadap praktik vulva hygiene. Setelah diberi metode pembelajaran peer teaching, maka nilai rerata praktik mahasiswa meningkat.

\section{Pembahasan}

Komponen yang terdapat dalam metode pembelajaran peer teaching yaitu adanya tutor dan tutee. Seorang tutor dipilih berdasarkan peringkat terbaik nilai pretest sebelumnya dan bersedia untuk dibimbing dan dilatih menjadi seorang tutor, mampu melakukan dan mengajarkan praktik pertolongan letak sungsang secara benar serta mampu berkomunikasi dengan baik. Berdasarkan pendapat Budiman dan Riyanto (2013) yang mengemukakan bahwa pengalaman belajar dan bekerja yang dikembangkan akan memberikan pengetahuan dan ketrampilan profesional.

Berdasarkan hasil penelitian nilai posttest didapatkan data yang menunjukkan bahwa semua mahasiswa $(100 \%)$ telah mendapatkan nilai praktik di atas KKM. Hal ini berarti terjadi peningkatan nilai praktik mahasiswa pada praktik vulva hygiene. Beberapa hal yang menyebabkan terjadinya peningkatan keterampilan ini diantaranya karena mereka telah mendapatkan materi dan bimbingan intensif dari tutor tentang praktik vulva hygiene melalui metode pembelajaran peer teaching. Hal ini menyebabkan mahasiswa mampu dan cakap dalam melakukan praktik.

Hisyam Zaini dalam Hafizah (2013) mengatakan bahwa metode belajar yang paling baik adalah dengan mengajarkan kepada orang lain. Oleh karena itu, pemilihan metode pembelajaran peer teaching (tutor sebaya) sebagai strategi pembelajaran akan sangat membantu siswa di dalam mengajarkan materi kepada teman-temannya untuk menumbuhkan dan meningkatkan persaingan hasil belajar. Selain itu sesuai dengan teori yang dikemukakan oleh Dedi Supriyadi dalam Suherman (2008) bahwa tutor sebaya adalah seorang atau beberapa orang siswa yang ditunjuk dan ditugaskan utuk membantu atau membimbing yang mengalami kesulitan belajar. Model tutor sebaya yang dimaksud yaitu bagaimana mengoptimalkan kemampuan peserta didik yang berprestasi dalam satu kelas untuk mengajarkan atau menularkan kepada teman sebaya mereka yang kurang berprestasi, sehingga peserta didik yang kurang berprestasi bisa mengatasi ketertinggalan.

Keuntungan dari metode pembelajaran praktikum peer teaching (tutor sebaya) yaitu untuk memupuk rasa kerjasama dan saling membantu, 
meningkatkan kemampuan baik tutor maupun yang ditutori, membentuk rasa bangga pada diri orang yang menjadi tutor, menularkan kemampuan yang dimiliki tutor yang selama ini hanya digunakan untuk dirinya sendiri, dan memudahkan bagi peserta didik yang ditutori dalam menerima penjelasan karena tutor menggunakan bahasa yang mudah dipahami (Aria Djalil dalam Hafizah, 2011).

Hal ini sesuai dengan pendapat Whiterington dalam Nuryadi (2012) yang menyatakan bahwa mahasiswa yang mendapat kesempatan untuk melihat dan mendengar orang lain melakukan praktik dan diberi kesempatan untuk melakukannya sendiri saat pembelajaran berlangsung menyebabkan perubahan yang meningkat dan progresif pada dirinya.

Tresnaningsih (2011) menyebutkan bahwa peningkatan nilai mahasiswa mengindikasikan bahwa terdapat peningkatan aktivitas intelektual mahasiswa. Peningkatan nilai dan rerata ini terjadi karena dengan menggunakan metode pembelajaran peer teaching (tutor sebaya) beberapa anak yang mempunyai perasaan takut atau enggan kepada pembimbing, menjadi lebih aktif dan berani dalam pembelajaran. Sawali dalam Hafizah (2011) menyebutkan bahwa peer teaching (tutor sebaya) adalah kegiatan belajar peserta didik dengan memanfaatkan teman sekelas yang mempunyai kemampuan lebih untuk membantu temannya dalam melaksanakan suatu kegiatan atau memahami suatu konsep. Hasil penelitian ini juga sejalan dengan penelitian yang dilakukan oleh Ruseno Arjanggi dan Titin Suprihatin (2010) yang menemukan ada pengaruh penggunaan metode tutor teman sebaya terhadap hasil belajar berdasar regulasi diri pada mahasiswa.

Adanya pengaruh metode pembelajaran tutor sebaya ini juga sejalan dengan pendapat Mustofa Arif (2009) bahwa seorang anak pada usia remaja cenderung untuk membuat sebuah kelompok yang disebut dengan peer group yang merupakan tempat belajar dan bermain bersama antara teman sebaya dengan tujuan yang sama. Di dalam kelompok sebaya anak belajar memberi dan menerima dalam hal apapun. Pergaulan peer group adalah kontak langsung antara individu satu dengan individu lain dalam kelompok anak sebaya. Dengan adanya motivasi belajar yang tinggi pada diri siswa, maka prestasi belajar yang diperoleh juga semakin tinggi. dan dengan bergaul dengan teman sebaya yang baik, maka akan menunjang proses belajar yang maksimal dan prestasi belajar yang tinggi.

\section{SIMPULAN DAN SARAN}

\section{Simpulan}

Hasil penelitian menunjukkan bahwa nilai praktik vulva hygiene sebelum diberikan metode pembelajaran praktikum peer teaching mayoritas mahasiswa $(77,8 \%)$ mendapat nilai praktik di bawah KKM dan setelah diberikan metode pembelajaran praktikum peer teaching semua mahasiswa (100\%) mendapatkan nilai praktik di atas KKM, sehingga dapat disimpulkan ada pengaruh metode pembelajaran praktikum peer teaching terhadap praktik pertolongan letak sungsang pada mahasiswa DIII Kebidanan Fakultas Kedokteran UNS 


\section{Saran}

Mahasiswa diharapkan lebih aktif lagi dalam pembelajaran terbimbing mandiri di laboratorium sehingga dapat meningkatkan keterampilan praktik yang dimilikinya dan metode praktikum peer teaching dapat digunakan sebagai alternatif metode pembelajaran student centre learning oleh dosen dalam pembelajaran skills lab.

\section{DAFTAR PUSTAKA}

Arif M., 2009. Hubungan Antara Motivasi Belajar dan Pergaulan Peer Group dengan Prestasi Belajar Sosiologi kelas XI SMA Muhammadiyah 2 Gemolong Tahun 2008/2009. Universitas Sebelas Maret. Skripsi

Arjanggi R dan Titin S., 2010. Metode Pembelajaran Tutor Teman Sebaya Meningkatkan Hasil Belajar Berdasarkan Regulasi Diri. Makara:Sosial Humaniora. Volume:14 No:2, pp.91-97.

Budiman dan Agus R., 2013. Kapita Selekta Kuesioner. Jakarta, Salemba Medika, pp.4.

Blanch S., Duran D., Valdebenito V., \& Flores M., 2013. The Effects And Characteristics Of Family Involvement On A Peer Tutoring Programme To Improve The Reading Comprehension Competence. European Journal of Psychology of Education, 28(1), 101-119.

Bowman PL., Davis H., Vannest K., Williams L., Greenwood C., \& Parker R., 2013. Academic Benefits Of Peer Tutoring: A Meta-Analytic Review Of Single Case Research. School Psychology Review, 42(1), 39-55.

Depdiknas., 2010. Pengembangan Perangkat Penilaian Psikomotor. Jakarta, Depdiknas.

Djamarah SB dan Aswan Z., 2013. Strategi Belajar Mengajar. Jakarta, Rineka Cipta, pp. 26-28.

Hafizah., 2013. Pengaruh Metode Tutor Sebaya Terhadap Hasil Belajar di Kelas $V$ Sekolah Dasar Kota Pontianak. Universitas Tanjungpura Pontianak. Skripsi.

Imanudin., 2010. Model Pembelajaran Kooperatif Tutor Sebaya Dalam Mata Pelajaran Matematika Untuk Meningkatkan Kemampuan Pemahaman. Universitas Pendidikan Indonesia. Thesis.

Jufna S., 2012. Keefektifan Penerapan Model Pembelajaran Student Facilitator and Explaining terhadap Peningkatan Aktivitas dan Prestasi Belajar Kimia. Universitas Negeri Yogyakarta. Skripsi.

Kementrian Kesehatan RI, 2007, Keputusan Menteri Kesehatan RI Nomor: 369/Menkes/SK/III/2007 tentang Standar Profesi Bidan, Jakarta

Majid A., 2014. Strategi Pembelajaran. Bandung, Remaja Rosdakarya, pp.206-7.

Roscoe RD \& Chi MTH., 2007. Understanding Tutor Learning: Knowledge Building And Knowledgetelling In Peer Tutors' Explaination And Questions. Review of Education Research, 77 (4): 534-574. 
Jurnal Kebidanan Indonesia. Vol 11 No 1. Januari 2020 (90 - 97)

Sukiarko E., 2007. Pengaruh Penelitian Dengan Metode Belajar berdasarkan Masalah Terhadap Pengetahuan dan Keterampilan Kader Gizi dalam Kegiatan Posyandu. Universitas Diponegoro. Thesis.

Syahputra Y., 2011. Penerapan Metode Tutor Sebaya Untuk Meningkatkan Hasil Belajar Siswa Kelas VIII B Mata Pelajaran Teknologi Informasi dan Komunikasi di Madrasah Tsanawiyah Al-Inayah Sarijadi Bandung. Universitas Pendidikan Indonesia. Skripsi.

Tresnaningsih R., 2011. Pembelajaran Aktif Untuk Meningkatkan Kemampuan Berfikir Tingkat Tinggi Melalui Keterampilan Menyelesaikan Masalah Pada Perkuliahan Kalkulus Lanjut. IKIP PGRI Madiun. Skripsi

Tsuei M., 2014. Mathematics Synchronous Peer Tutoring System for Students with Learning Disabilities. Educational Technology \& Society, 17(1), 115217. 